\title{
Effective Role of Beneficial Microbes in Achieving the Sustainable Agriculture and Eco-Friendly Environment Development Goals: A Review
}

\author{
Narendra Kumar Ahirwar, ${ }^{1,}$, Ravindra Singh ${ }^{1}$, Sadhana Chaurasia ${ }^{1}$, Ramesh Chandra ${ }^{1}$, \\ Shailendira Prajapati ${ }^{1}$, Sivakoti Ramana ${ }^{2}$ \\ ${ }^{1}$ Department of Biological Sciences, Mahatma Gandhi Chitrakoot Gramodaya Vishwavidyalaya Chitrakoot, Satna, India \\ ${ }^{2}$ Soil Biology Division, Indian Institute of Soil Science, Bhopal, India
}

\section{Email address:}

narendra87.ahirwar@gmail.com (N. K. Ahirwar)

${ }^{*}$ Corresponding author

\section{To cite this article:}

Narendra Kumar Ahirwar, Ravindra Singh, Sivakoti Ramana. Effective Role of Beneficial Microbes in Achieving the Sustainable Agriculture and Eco-Friendly Environment Development Goals: A Review. Frontiers in Environmental Microbiology.

Vol. 5, No. 6, 2019, pp. 111-123. doi: 10.11648/j.fem.20190506.12

Received: July 12, 2019; Accepted: August 4, 2019; Published: January 8, 2020

\begin{abstract}
Agriculture have a significant portion of the economies of world and therefore can contribute toward major continental priorities such as eradicating poverty, hunger, rapid industrialization, economic diversification, sustainable resource utilization, investments, and environmental management. Plant-associated microbiomes have tremendous potential to improve plant resilience and yields in farming systems. There is increasing evidence that biological technologies that use microbes or their metabolites can enhance nutrient uptake and yield, control pests and mitigate plant stress responses. Microbiological achievements of recent years have emerged as powerful tool to improve quality attributes of sustainable agriculture and environmental health. The chemical fertilizers used in the agriculture to increase yields but kill microflora, pests, and weeds, it have a big harmful impact on the ecosystem. Because of current public concerns about the side effects of agrochemicals, there is an increasing interest in improving the understanding of cooperative activities among plants and rhizosphere microbial populations. The review deals with microbes in biotechnology and their diversified applications in agriculture as bio-fertilizers, bio-pesticides, bio-herbicides, bio-insecticides, fungal based bio-insecticides and viral based bioinsecticides. Finally, a brief highlight has been given on the role of microbiology on development of sustainable agriculture and environment friendly approach to increase crop production and environmental health.
\end{abstract}

Keywords: Sustainable Agriculture, Bio-Fertilizers, Bio-Pesticides, Bio-Herbicides, Environmental Health

\section{Introduction}

The need for chemical free agricultural practices is becoming eminent due to the effects of these chemicals on the environment and human health. As countries develop, people are also demanding more and better food. These pressures are multiplied by shrinking farmland, rising labour costs and shortage of farm workers. Conventional intensive agricultural practices that depend on inorganic fertilizers, pesticides and other chemical inputs have increased yield but also contributed to soil degradation, loss of biodiversity, increased susceptibility of crops to pests/pathogens and negative environmental impacts which, together, have significant consequences for human health and food security [1]. In addition to structural decline in farm productivity in developed countries, major challenges in developing countries lie in substantially increasing yield quality and quantity, without further increases in farming costs and detrimental environmental impacts.

The potential benefits of microbiology are numerous and include providing resistance to crop pests, increasing crop yield and reducing chemical pesticide usage. Agricultural technologies that ensured a 'green revolution' in the middle of 20th century, causing now high ecological cost and contributing global pollution, unfavourable climate change and loss of biodiversity [2]. The broad application of 
microbes in sustainable agriculture is due to the genetic dependency of plants on the beneficial functions provided by symbiotic co-habitants [3]. Therefore, microbial biotechnology and its applications in sustainable development of agriculture and environmental health are getting better attention. Interest in the microbial biodegradation of pollutants has intensified in recent years as mankind strives to find sustainable ways to clean up contaminated environments. These bioremediation and biotransformation methods use the naturally occurring, microbial catabolic diversity to degrade, transform or accumulate a huge range of compounds including hydrocarbons, polychlorinated biphenyls (PCBs), polyaromatic hydrocarbons (PAHs), pharmaceutical substances, radionuclide's and heavy metals [4].

In agriculture, what farmers want in their crops are traits such as high yield, disease resistance, insect pest resistance, and quality such as higher nutrients, color, texture, and taste. Agriculture in many parts of the world is undergoing a major strategic restructuring to achieve vertical integration between production and utilization. Genetic engineering is creating a revolution in agriculture allowing an ever-increasing range of plants and animals. Scientists are concerned with finding the earth's human production hope to use recombinant technology to improve productivity of plants and animals important to agriculture. Agricultural microbiology is presented as a synthetic research field responsible for knowledge transfer from general microbiology and microbial ecology to the agricultural biotechnology. A fundamental knowledge of the genetics, molecular biology ecology, and evolution of symbiotic interactions could enable the development of microbe-based sustainable agriculture. Undoubtedly, getting biased rhizosphere opens new opportunities for future agricultural developments based on exploiting the beneficial microbial services to reduce the inputs of agrochemicals, thereby reaching sustainable environmental and economical goals.

\section{Problems, Challenges and Opportunities}

Scientists are aware on addressing their research efforts to face a critical problem derived from the need to feed a growing, and more and more urbanized, world population. Actually, 10.2 billion people are expected to inhabit the Planet by 2050 , with a particular incidence in developing countries in the world. Consequently, many so challenges arise, basically, the need to produce more healthy food, fiber and bio-energy, while preserving the biosphere. An intensive agricultural production appears necessary, however these practices imply the mass consumption of non-renewable natural resources, such as fossil fuel and other energy sources, water, agricultural soil, rock phosphate reserves, etc. In addition, both the energy intensive industrial processes for the production of fertilizers, and the runoff or leaching of soluble nutrients from the applied agrochemicals into the aquatic systems, are sources of environmental contamination [5]. The environmental pollution of toxic heavy metals is the major problem throughout the world since industrial evolution. Industrial wastes are major source of heavy metals pollution in India due to inadequate wastewater treatment system. Heavy metals are harmful to humans and animals, tending to accumulate in the food chain [6-9]. Restoration of soils contaminated with potentially toxic metals and metalloidsis of major global concern. Considerable efforts have been made to develop suitable methods for the remediation of contaminated soils [10]. Besides, intensive agriculture is known to cause an increase in the production of "greenhouse gases", thereby rising Earth's temperature, thus affecting biosphere stability [11]. Consequently, diverse types of stress situations are generated by intensive agricultural practices, all of them impacting on the functionality/productivity of both agricultural systems and natural ecosystems, and limit the services that these are able to provide. The responsible stress factors include salinity, drought, nutrient deficits, contamination, soil erosion, diseases, pests, plant invasions, etc. In addition, the application of agrochemicals to control biotic stresses and nutrient deficiencies provokes environmental contamination and may threat human health. In summary, the above indicated ecological constraints impact on agro-ecosystems and cause agricultural and forest productivity losses, soil erosion, water deficit, biodiversity losses, landscape fragmentation, etc [12].

Agricultural practices are currently implemented on a global scale and different approaches are being addressed to meet sustainable environmental and economical developments with the final aims of maintaining yield while preserving the biosphere. "Sustainable development" as the result of the intersections among three primary factors: environment, society and economy, which in turn interact between each two of them [13]. Therefore, the intersection economy-environment (agro-ecology), environment-society (environmental awareness), and society-economy (life standard), finally determines the concept/action of "sustainable development". In a sustainability context, a key issue is maintaining the quality of the soil, a non-renewable resource, which exerts many environmental and social functions some of them are driven by soil microbes [14]. A target in sustainability is to find out efficient methods for recycling nutrients, controlling pest and pathogens, and for alleviating the negative impact of abiotic stress factors, fundamental issues for human life and for the sustainability of global ecosystems. These activities are typical microbial services, which can be exploited after an appropriate management of beneficial microorganisms and their functions [15]. Accordingly, the role and management of the root-associated microbiome, essential to meet both economically and ecologically sustainable issues, is analyzed first in this article. 


\section{Microbes and Biotechnology}

Microbes are mostly microscopic small creatures are placed in different groups such bacteria, fungi, protozoa, micro-algae and viruses. These organisms live in soil, air, water, space, glacier, food, animal intestines and other different environments. Various microbial habitats reflect an enormous diversity of biochemical and metabolic traits that have arisen by genetic variation and natural selection in microbial populations. Men used some of microbial diversity in the production of fermented foods such as yogurt, butter, bread, and cheese. Some soil microbes release nitrogen through the nitrogen fixation that plants need for better growth and emit gases that maintain the critical composition of the Earth's atmosphere.

Other microbes challenge the food supply by causing yield-reducing diseases in food-producing plants and animals. In our bodies, different microbes help to digest food, ward off invasive organisms, and engage in skirmishes and pitched battles with the human immune system in the give-and-take of the natural disease process. Genome is the totality of genetic material in the DNA of a particular organism. Genomes differ greatly in size and sequence across different organisms. Obtaining the complete genome sequence of a microbe provides crucial information about its biology, but it is only the first step toward understanding a microbe's biological capabilities and modifying them, if needed, for agricultural purposes. Microbial biotechnology, enabled by genome studies, will lead to breakthroughs such as improved vaccines and better disease-diagnostic tools, improved microbial agents for biological control of plant and animal pests, modifications of plant and new animal pathogens for reduced virulence, development of new industrial catalysts and fermentation organisms, and development of new microbial agents for bioremediation of soil and water contaminated by anthropogenic, industrial and agricultural runoff. Therefore, researchers have proposed safe, economically feasible and eco-friendly approaches for bioremediation using microorganisms and non-edible plants $[16,17]$. Microbial biotechnology is an important area that promotes for advances in crop yield, food safety, food security, value-added products, human nutrition and functional foods, plant and animal production and protection, and overall fundamental research in the agricultural sciences.

\section{Microbiom's and Its Applications in Agriculture}

Sustainable agriculture is vitally important because it offers the potential to meet our future agricultural needs, something that conventional agriculture will not be able to do. Sustainable crop production could be achieved only by the application of plant growth promoting microbes in an integrated manner without further deterioration in soil health. Microorganisms are recognized as the potential tools for sustainable agriculture because they not only ensure the availability of essential nutrients to plants but also enhance the nutrient use efficiency. Due to food safety issues and increasing environmental concerns, the usage of biofertilizers, bio-pesticides and bio-herbicides is gaining attention in the agriculture sector world-wide [18]. The antagonistic or plant growth promoting rhizobacteria (PGPR) and their bioactive antimicrobial compounds are considered as environmental friendly and easily biodegradable. Microorganisms used chemical contaminants as an energy source using their metabolic process throughout the microbiological process. However, the excessive amounts inorganic nutrients in soil cause microbial inhibition4. The microorganisms in particular have the abilities to degrade, detoxify and even accumulate the harmful organic as well as inorganic compounds [19]. Soil microorganisms vary widely in their tolerance to heavy metal contamination, and the proportion of culturable resistant microorganisms can range from $10 \%$ to nearly $100 \%$. The activities of enzymes in soil may serve as indicators of heavy metal contamination, as there are generally high correlations between reduced enzyme activities (of, e.g., dehydrogenases, acid phosphatases and ureases) and increased heavy metal contamination [20]. It has been reported that heavy metal contamination has different effects on soil bacteria and fungi [21]. Hence, they can be the key players in the sustainable agriculture [22].

The bacterial generasuch as Agrobacterium, Arthrobacter, Azotobacter, Azospirillum, Bacillus, Burkholderia, Caulobacter, Chromobacterium, Erwinia, Flavobacterium, Micrococcous, Pseudomonas and Serratiabelong toextracellular plant growth promoting rhizobacteria [23]. The intracellular plant growth promoting rhizobacteria belongs to the family of Rhizobiaceae includesAllorhizobium, Bradyrhizobium, Mesorhizobiumand Rhizobium, endophytes and Frankia species both of which can symbiotically fixatmospheric nitrogen with the higher plants [24, 25]. PGPR enrich the soil environment with micro- and macronutrients by means of nitrogen fixation, phosphate/potassium/zinc solubilisations or mineralization, release of plant growth regulating substances, degradation of organic matter [26], and can control plant pathogens, especially the fungus, by producing antifungal metabolites or through induction of systemic resistance. In agriculture, farmers want in their crops are traits such as high yield, disease resistance, insect pest resistance, and quality such as higher nutrients, color, texture, and taste. Agriculture in many parts of the world is undergoing a major strategic restructuring to achieve vertical integration between production and utilization. Currently, PGPR inoculants consist of the bacteria mainly from the genus Rhizobium (symbiotic $\mathrm{N}_{2}$-fixing bacteria), Azospirillum (free living $\mathrm{N}_{2}$ fixing bacteria), Bacillus (phosphate-solubilizing bacteria and biocontrol agents), Pseudomonas and Trichoderma (biocontrol agents) [27-29].

Our previous investigation were studied the physiological basis of yield improvement with the application of $P$. fluorescence (SS5). To quantify the effect of $P$. fluorescence on yield by the tomato plants and to ascertain the mode of 
action of $P$. fluorescence in plants in pot culture, and field trials $P$. fluorescence (SS5) enhanced the growth of tomato plants. Significant increase in root and shoot weight, length, fruit yield per plant, and total fruit yield was recorded. The strain SS5 was significantly rhizopheric competent and stabilized in the rhizosphere, without disturbing the normal indigenous bacterial population [30].

In recent years, the use of Azospirillum, Azotobacter, Bacillus, Pseudomonas, Enterobacter, Arthrobacter, andBurkholderia, others has reported to enhance efficiency of fertilizers, mitigate abiotic stresses, manage plant pathogens, cause the degradation of xenobiotic compounds and enhance plant growth dramatically in various parts of the world [31-34]. Beneficial rhizobacteria have potential as part of an overall management system to reduce the use of synthetic compounds and fertilizer and provide a sustainable agriculture [35, 36]. Genetic engineering is creating a revolution in agriculture allowing an ever-increasing range of plants and animals. Scientists are concerned with finding the earth's human production hope to use recombinant technology to improve productivity of plants and animals important to agriculture.

\section{Eco-Friendly Environment}

\subsection{Seed Inoculants}

Microbial inoculants applied as seed treatments deliver microorganisms directly to the plant rhizosphere, the narrow zone of soil that surrounds the roots where plants interact directly with microorganisms [37]. It is a zone of intense microbial activity, with growth of plants and microorganisms dependent on reciprocal provision of nutrients and a wide range of other compounds including plant growth regulators and antibiotics. Many beneficial microorganisms of agricultural importance are rhizosphere colonizing species, with ability to increase plant growth via a range of mechanisms [38].

\subsection{Bio-Fertilizers}

Microorganisms found in the soil to improve agricultural productivity. Men use naturally occurring organisms to develop bio-fertilizers and bio-pesticides to assist increase plant growth and control weeds, pests, and diseases. Microorganisms that live in the soil actually help plants to absorb more nutrients. Plants and these friendly microbes are involved in "nutrient recycling". The microbes help the plant to "take up" essential energy sources. In return, plants donate their waste by-products for the microbes to use for food. Scientists use these friendly microorganisms to develop different kind of beneficial bio-fertilizers. Our present day life styles environmental pollution is a major cause of concern. The use of the chemical fertilizers to meet the everincreasing demand of agricultural produce has contributed significantly to this pollution. Of course, we have now realized that there are problems associated with the overuse of chemical fertilizers and there is a large pressure to switch to organic farming the use of bio-fertilizers. Bio-fertilizers are organisms that enrich the nutrient quality of the soil.

Most of the bacteria and fungi included in bio-fertilizer have close relationship with plant roots. The phosphorus solubilizing microorganisms (PSMs) mainly bacteria and fungi make insoluble phosphorus available to the plants. Several soil bacteria and a few species of fungi possess the ability to bring insoluble phosphate in soil into soluble forms by secreting organic acids [39]. These acids lower the soil $\mathrm{pH}$ and bring about the dissolution of bound forms of phosphate. While Rhizobium, blue-green algae (BGA) and Azollaare crop specific, bioinoculants like Azotobacter, Azospirillum, phosphorus solubilizing bacteria (PSB) and vesicular arbuscular mycorrhiza (VAM) could be regarded as broad spectrum bio-fertilizers ${ }^{39}$. Free-living nitrogen-fixing bacteria are Azotobacter, Azospirillum, Clostridium pasteurianum, Rhodobacter, cyanobacteria and some methanogens. Ksolubilizers is $B$. mucilaginous while for P-solubilizers are $B$. megaterium, B. circulans, B. subtilis and P. striata [40, 41].

The main sources of bio-fertilizers are bacteria, fungi and cyanobacteria. You have studied about the nodules on the roots of leguminous plants formed by the symbiotic association of rhizobium. These bacteria fix atmospheric nitrogen into organic forms, which is used by the plant as nutrient. Other bacteria can fix atmospheric nitrogen while free-living in the soil (Azospirillum and Azotobacter), thus enriching the nitrogen content of the soil. Fungi are also known to form symbiotic associations with plants (mycorrhiza). Many members of the genus Glomus form mycorrhiza. The fungal symbiont in these associations absorbs phosphorus from soil and passes it to the plant. Plants having such associations show other benefits also, such as resistance to root-borne pathogens, tolerance to salinity and drought, and an overall increase in plant growth and development. Cyanobacteria are autotrophic microbes widely distributed in aquatic and terrestrial environments many of which can fix atmospheric nitrogen (Anabaena, Nostoc, Oscillatoriaetc). In paddy fields, cyanobacteria serve as an important bio-fertilizer. Blue green algae also add organic matter to the soil and increase its fertility. Currently, in our country, a number of bio-fertilizers are available commercially in the market and farmers use these regularly in their fields to replenish soil nutrients and to reduce dependence on chemical fertilizers.

Phosphate and nitrogen are important for the growth of plants. These compounds exist naturally in the environment but plants have a limited ability to extract them. Phosphate plays an important role in crop stress tolerance, maturity, quality and directly or indirectly, in nitrogen fixation. A fungus, Penicillium bilaii helps to unlock phosphate from the soil. It makes an organic acid, which dissolves the phosphate in the soil so that the roots can use it. Bio-fertilizer made from this organism is applied by either coating seeds with the fungus as inoculation, or putting it directly into the ground. Rhizobium is a bacteria used to make bio-fertilizers. This bacterium lives on the plant's roots in cell collections called nodules. The nodules are biological factories that can take 
nitrogen out of the air and convert it into an organic form that the plant can use.

This fertilization method has been designed by nature. With a large population of the friendly bacteria on its roots, the legume can use naturally-occurring nitrogen instead of the expensive traditional nitrogen fertilizer. Bio-fertilizers help plants use all of the food available in the soil and air, thus allowing farmers to reduce the amount of chemical fertilizers they use. This helps preserve the environment for the generations to come.

\subsection{Bio-Pesticides}

'Bio-pesticides' are certain types of pesticides derived from such natural materials as animals, plants, bacteria, and certain minerals. These include for example; fungi such as Beauveria sp., bacteria such as Bacillus sp., neem extract and pheromones. Similarly Canola oil and baking soda have pesticide applications and are considered as bio-pesticides. In a much simpler way we can say that these are pest management tools that are based on beneficial microorganisms (bacteria, viruses, fungi and protozoa), beneficial nematodes or other safe, biologically based active ingredients. Benefits of bio-pesticides include effective control of insects, plant diseases and weeds, as well as human and environmental safety. Bio-pesticides also play an important role in providing pest management tools in areas where pesticide resistance, niche markets and environmental concerns limit the use of chemical pesticide products [42]. The most widely known microbial pesticides are varieties of the bacterium Bacillus thuringiensis (Bt) which can control certain insects in cabbage, potato, and other crops. Bt produces a protein that is harmful to specific insect pest. Certain other microbial pesticides act by out-competing pest organisms. Microbial pesticides need to be continuously monitored to ensure that they do not become capable of harming non-target organisms, including humans.

Plant growth promoting rhizobacteria (PGPR) are functionally diverse group of bacteria having immense potential as bio-fertilizers and bio-pesticides. Depending upon their function, they may serve as partial replacements for chemical fertilizer or pesticides as an eco-friendly and cost-effective alternatives as compared to their synthetic counterparts [43]. Microorganisms found in the soil are all not so friendly to plants. These pathogens can cause disease or damage the plant. As scientists developed biological "tools," which use these disease-causing microbes to control weeds and pests naturally. Development of bio-pesticides industry has to be treated as a strategic, comprehensive and forward looking task [44]. The ongoing population and the growing need of the population need more supply of the crops and other products. The increasing concern of consumers and government on food safety has led growers to explore new environmentally friendly methods to replace, or at least supplement, the current chemical-based practices. The use of bio-pesticides has emerged as promising alternative to chemical pesticides. Bio-pesticides have a precious role to play in the future of the Integrated Pest
Management strategies.

\subsection{Microbial Pesticides}

Microbial bio-pesticides represent an important option for the management of plant diseases. The United States Environmental Protection Agency (EPA) defines biopesticides as, "certain types of pesticides derived from such natural materials as animals, plants, bacteria, and certain minerals." Microbial pesticides contain a microorganism (bacterium, fungus, virus, protozoan or alga) as the active ingredient. Microbial pesticides can control many different kinds of pests, although each separate active ingredient is relatively specific for its target pests. For example, there are fungi that control certain weeds, and other fungi that kill specific insects. They suppress pest by producing a toxin specific to the pest, causing a disease. Preventing establishment of others microorganisms through competition or other modes of action. The most widely known microbial pesticides are varieties of the bacterium Bacillus thuringiensis $(\mathrm{Bt})$ [45], which can control certain insects in cabbage, potato, and other crops. Bt produces a protein that is harmful to specific insect pest. Certain other microbial pesticides act by out-competing pest organisms. Microbial pesticides need to be continuously monitored to ensure that they do not become capable of harming non-target organisms, including humans and other organisms. Bt can be applied to plant foliage or incorporated into the genetic material of crops and as discovered, it is toxic to the caterpillars (larvae) of moths and butterflies. These also can be used in controlling mosquitoes and black flies. Several strains of Bt have been developed and now strains are available that control fly larvae. While some Bt's control moth larvae found on plants, other Bt's are specific for larvae of flies and mosquitoes. The target insect species are determined by whether the particular Bt produces a protein that can bind to a larval gut receptor, thereby causing the insect larvae to starve [46]. Entomo pathogenic fungi are important natural regulators of insect populations and have potential as mycoinsecticide agents against diverse insect pests in agriculture.

\subsection{Bio-Herbicides}

Bio-herbicides serves a more important role as a complimentary component in successful integrated management strategies [47], and not as a replacement for chemical herbicides and other weed management tactics [48]. Bio-herbicides include phytopathogenic microorganisms or microbial compounds useful for weed control. Collectively these organisms and/or their natural products are called bioherbicides. Many microbes have bio-herbicidal activity, and several phytopathogenic fungi and bacteria have been patented as weed-control agents. The phytotoxic components of most agents have not been elucidated, but some phytotoxins and other secondary compounds produced by such microbes may be toxic to mammalian systems. Furthermore, few rigorous assessments have addressed 
uptake, translocation, metabolism, and persistence of these phytotoxins (some of which have not been identified), or the environmental effects of repeated augmentative applications of these microorganisms on long-term impact, environmental fate, or interactions with other microbial communities. Generally, there is a lack of definitive research on the overall toxicological risk of bio-herbicidal microorganisms to the degree achieved or required for synthetic herbicides. Weeds are the problem for farmers. They not only compete with crops for water, nutrients, sunlight, and space but also harbor insect and disease pests; clog irrigation and drainage systems; undermine crop quality; and deposit weed seeds into crop harvests.

Bio-herbicides are another way of controlling weeds without environmental hazards posed by synthetic herbicides. The microbes possess invasive genes that can attack the defense genes of the weeds, thereby killing it. The benefit of using bio-herbicides is that it can survive in the environment long enough for the next growing season where there will be more weeds to infect. It is cheaper than synthetic pesticides thus could essentially reduce farming expenses if managed properly. Further, it is not harmful to the environment compared to conventional herbicides and will not affect nontarget organisms.

\subsection{Bio-Insecticides}

Synthetic chemical insecticides provide many benefits to food production and human health, but they also pose some hazards. In many instances, alternative methods of insect management offer adequate levels of pest control and pose fewer hazards. One such alternative is the use of microbial insecticides- -insecticides that contain microorganisms or their by-products. Microbial insecticides are especially valuable because their toxicity to non target animals and humans is extremely low. Compared to other commonly used insecticides, they are safe for both the pesticide user and consumers of treated crops. Microbial insecticides also are known as biological pathogens, and biological control agents [49].

Biotechnology can also help in developing alternative controls to synthetic insecticides to fight against insect pests. Formulas for coatings on the seed (inoculants) which carry these beneficial organisms can be developed to protect the plant during the critical seedling stage. Bio-insecticides do not persist long in the environment and have shorter shelf lives; they are effective in small quantities, safer to humans and animals compared to synthetic insecticides; they are very specific, often affecting only a single species of insect and have a very specific mode of action; slow inaction and the timing of their application is relatively critical. Microbial insecticides are comprised of microscopic living organisms (viruses, bacteria, fungi, protozoa, or nematodes) or the toxins produced by these organisms. They are formulated to be applied as conventional insecticidal sprays, dusts, liquid drenches, liquid concentrates, wettable powders, or granules. Each product's specific properties determine the ways in which it can be used most effectively [50].

\subsection{Bacterial Bio-Insecticides}

Bacterial pathogens used for insect control are sporeforming, rod-shaped bacteria in the genus Bacillus. They occur commonly in soils, and most insecticidal strains have been isolated from soil samples. Bacterial insecticides must be eaten to be effective; they are not contact poisons. Insecticidal products comprised of a single Bacillus species may be active against an entire order of insects, or they may be effective against only one or a few species. For example, products containing Bacillus thuringiensis var. kurstaki kill the caterpillar stage of a wide array of butterflies and moths. In contrast, Bacillus popillae (milky spore disease) kills Japanese beetle larvae but is not effective against the closely related annual white grubs (masked chafers in the genus Cyclocephala) that commonly infest lawns.

The microbial insecticides most widely used in the United States since the 1960s are preparations of the bacterium Bacillus thuringiensis. $\mathrm{Bt}$ products are produced commercially in large industrial fermentation tanks. As the bacteria live and multiply in the right conditions, each cell produces (internally) a spore and a crystalline protein toxin called an endotoxin. Most commercial Bt products contain the protein toxin and spores, but some are cultured in a manner that yields only the toxin component [51, 52]. Insecticides sold under the trade names Doom $\AA$, Japidemic ${ }^{\circledR}$, Grub Attack ${ }^{\circledR}$, and the generic name "milky spore disease" contains the bacteria Bacillus popillae and Bacillus lentimorbus. These bacteria cannot be grown in fermentation tanks; instead, they are "cultivated" in laboratory-reared insect larvae.

\subsection{Fungal Bio-Insecticides}

Fungi, like viruses, often act as important natural control agents that limit insect populations. Most of the species that cause insect diseases spread by means of asexual spores called conidia. Although conidia of different fungi vary greatly in ability to survive adverse environmental conditions, desiccation and ultraviolet radiation are important causes of mortality in many species. Where viable conidia reach a susceptible host, free water or very high humidity is usually required for germination. Unlike bacterial spores or virus particles, fungal conidia can germinate on the insect cuticle and produce specialized structures that allow the fungus to penetrate the cuticle and enter the insect's body. Fungi do not have to be ingested to cause infections. In most instances, as fungal infections progress, infected insects are killed by fungal toxins, not by the chronic effects of parasitism. Beauveriabassiana, Nomuraearileyi, Vericilliumlecanii, Lagenidiumgiganteum and Hirsutellathompsonii fungi used as insecticides [53].

Fungi cause diseases in some 200 different insects and this disease producing traits of fungi is being used as bioinsecticides. Fermentation technology is used to mass production of fungi. Spores are harvested and packaged so these are applied to insect-ridden fields. When the spores are applied, they use enzymes to break through the outer surface 
of the insects' bodies. Once inside, they begin to grow and eventually cause death. Fungal agents are recommended by some researchers as having the best potential for long-term insect control. This is because these bio-insecticides attack in a variety of ways at once, making it very difficult for insects to develop resistance.

\subsection{Virus Based Bio-Insecticides}

The development and use of virus-based insecticides have been limited. Unlike Bt, insect viruses must be produced in live host insects. Production is therefore both expensive and time-consuming. These economic factors, coupled with the fact that some virus insecticides are considerably less effective than available synthetic chemical insecticides, have limited their development. Nonetheless, although they are not well known or widely available, several insect viruses have been developed and registered for use as insecticides. Most are specific to a single species or a small group of related forest pests, for example the gypsy moth, Douglas-fir tussock moth, spruce budworn, and pine sawfly. They are not commercially available but are produced and used by the United States Forest Service. Forest pests are especially good targets for viral pathogens because the permanence of the forest environment contributes to cycling of the pathogen (transmission from one generation to the next). The forest canopy also helps to protect viral particles from destruction by ultraviolet radiation.

Baculoviruses affect insect pests like corn borers, potato beetles, flea beetles and aphids. One particular strain is being used as a control agent for bertha army worms, which attack canola, flax, and vegetable crops. Traditional insecticides do not affect the worm until after it has reached this stage and by then much of the damage has been done. Other insect viruses investigated for use as insecticides include those that infect the alfalfa looper, soybean looper, armyworms, cabbage looper, and imported cabbageworm. Although some of these viruses have been formulated and applied in field tests, none has been registered or sold commercially. Both the codling moth GV (Decyde $\left.{ }^{\circledR}\right)$ and the Heliothis NPV (Elcar $\left.{ }^{\circledR}\right)$ were at one time registered by the US EPA and produced commercially, but these products are no longer registered or available.

\subsection{Protozoa Based Bio-Insecticides}

Protozoan pathogens naturally infect a wide range of insect hosts. Although these pathogens can kill their insect hosts, many are more important for their chronic, debilitating effects. One important and common consequence of protozoan infection is a reduction in the number of offspring produced by infected insects. Although protozoan pathogens play a significant role in the natural limitation of insect populations, few appear to be suited for development as insecticides. Species in the genera Nosema and Vairimorpha seem to offer the greatest potential for use as insecticides. Pathogens in these genera attack Lepidopteran larvae and insects in the order Orthoptera (the grasshoppers and related insects). The one protozoan currently available in a registered insecticidal formulation is the microsporidian. Microbial insecticides offer effective alternatives for the control of many insect pests. Their greatest strength is their safety, as they are essentially nontoxic and nonpathogenic to animals and humans. Although not every pest problem can be controlled by the use of a microbial insecticide, these products can be used successfully in place of more toxic insecticides to control many lawn and garden pests and several important field crop and forest insects. Because most microbial insecticides are effective against only a narrow range of pests and because these insecticides are vulnerable to rapid inactivation in the environment, users must properly identify target pests and plan the most effective application. But these same qualities mean that microbial insecticides can be used without undue risks of human injury or environmental damage. Consequently, microbial insecticides are likely to become increasingly important tools in insect management.

\section{Microbiology Ecology Biotechnology and Sustainable Agriculture}

Now increasing attention has been paid to the development of sustainable agriculture in which the high productivities of plants and animals are ensured using their natural adaptive potentials, with a minimal disturbance of the environment. It is our view that the most promising strategy to reach this goal is to substitute hazardous agrochemicals (mineral fertilizers, pesticides) with environment-friendly preparations of symbiotic microbes, which could improve the nutrition of crops and livestock, as well as their protection from biotic (pathogens, pests) and abiotic (including pollution and climatic change) stresses [54].

Therefore, agricultural microbiology is the present paramount research field responsible for the transfer of knowledge from general microbiology and microbial ecology to the agricultural biotechnologies. The present chapter is focused on plants, but also emphasizes the importance of micro-organisms in relation to agriculture and environmental health [55], and to the biocontrol of phytophagans [56].

The broad application of microbes in sustainable agriculture is due to the genetic dependency of plants on the beneficial functions provided by symbiotic cohabitants. The agronomic potential of plant-microbial symbioses proceeds from the analysis of their ecological impacts, which have been best studied for N2 fixing [57]. This analysis has been based on 'applied co-evolutionary research' [58], addressing the ecological and molecular mechanisms for mutual adaptation and parallel speciation of plant and microbial partners.

For plant-fungal interactions, it has been demonstrated that the host genotype represents the leading factor in the biogeographic distribution of mycobionts and for their evolution within the mutualist $\leftrightarrow$ antagonist and specialist $\leftrightarrow$ generalist continua [59]. The major impact of agricultural microbiology 
on sustainable agriculture would be to substitute agrochemicals (mineral fertilizers, pesticides) with microbial preparations. However, this substitution is usually partial and only sometimes may be complete, e.g. in recently domesticated leguminous crops, which retain a high potential for symbiotrophic nitrogen nutrition, typical for many wild legumes [60].

The application of nutritional symbionts could be based on plant mixotrophy, on a simultaneous symbiotrophic and combined $\mathrm{N}$ nutrition. This is why the maximal productivity of the majority of crops is reached using an optimal (species- and genotype-specific) combination of both nutritional types because of which a high sustainability of legume production may be achieved [61]. Moreover, the energy costs for $\mathrm{N}_{2}$ fixation and for assimilation of combined $\mathrm{N}$ differ by less than $10 \%$ [62]. The balance between symbiotrophic and combined $\mathrm{N}$ nutrition may be improved by a rapid removal of $\mathrm{N}$-compounds from the actively $\mathrm{N}_{2}$-fixing symbioses, as has been suggested for tropical forest ecosystems [63].

This approach is most promising in legume-rhizobia symbioses where the strong correlations between the ecological efficiency of mutualism and its genotypic specificity are evident. At present, a wide spectrum of preparations of diverse microbial species may be used to enhance crop production [64]. However, different approaches for improving the nutritional and defensive types of microbial mutualists need to be developed. For the nutritional types, an effective colonisation of plants in a host-specific manner is optimal and the impacts of beneficial symbionts are increased in parallel with their host specificity [65].

The application of microbial symbiotic signals or their derivatives for remodeling plant developmental or defensive functions may represent a promising field for agricultural biotechnology. The prospects for a future development of agricultural microbiology may involve the construction of novel multipartite endo and ecto symbiotic communities based on extended genetic and molecular (metagenomic) analyses. The primary approach for such construction is to create composite inoculants, which simulate the natural plant-associated microbial communities. For balancing the host plant metabolism, a combination of $\mathrm{N}$ - and P-providing symbionts would appear promising, including the endosymbiotic rhizobia + VAM-fungi [66].

The further development of agricultural microbiology faces several important ecological and genetic challenges imposed by the broad application of symbiotic microbes. Some of these challenges are associated with opportunistic or even regular human pathogens, which are frequently found in endophytic communities, including Bacillus, Burkholderia, Enterobacter, Escherichia, Klebsiella, Salmonella and Staphylococcus species [67]. An increased knowledge of microbe-based symbioses in plants could provide effective ways of developing sustainable agriculture in order to ensure human and animal food production with a minimal disturbance of the environment.
The effective management of symbiotic microbial communities is possible using molecular approaches based on the continuity of microbial pools which are circulating regularly between soil-, plant- and animal-provided niches in natural and agricultural ecosystems [68]. Analysis of this circulation could enable the creation of highly productive microbe-based sustainable agricultural system, whilst addressing the ecological and genetic consequences of the broad application of microbes in agricultural practice.

\section{Applications of Bacteria in Agriculture}

There are certain bacteria which contain special properties which are beneficent for plants. These bacteria are present in soil and they affect the crops by fighting against harmful bacteria and they are also the source of providing nutrition to the crops. Some bacteria like rhizobia and agro-bacteria are used to release seed inoculants and useful for the plants [69]. The bacteria like Azoarcusare of much importance for the plants that it fixes the endophyte of the grasses. This type of bacteria is mostly helpful crop of rice and they are very much environment friendly. When the seed is sown in the soil, bacteria play an important role in its germination. The bacteria grow in the seed in return get food from it. Bacteria increase the fertility of the soil and provide such nutrients to the soil which are useful for the plant growth [70]. They also help in softening the food in the seed and this is the reason plants come out of the seeds. Though it is not certain what role bacteria play when the plants grow but they are of much importance the early stages of plant development. Certain pesticides are developed using bacteria which give benefit to the crops. Bacillus thuringiensis is a gram positive bacterium in agriculture.

\section{Benefits of Mycorrhizal Fungi in Agriculture}

Mycorrhizal plants show increased growth and are generally more tolerant of adverse conditions such as drought [71], soil pathogens [72], transplantation, poor soil nutrient status and soil pollution [73], compared to non-micorrhizal controls. Improved plant growth and increased tolerance to adverse conditions can often be attributed to enhanced water and nutrient acquisition made possible by the extensive hyphal network which effectively increases the absorptive area of the root. However, the effectiveness of mycorrhizal fungi in increasing plant growth is not always directly related to the extent of root colonization or hyphal growth. In Eucalyptus globulus, plant dry weight was positively correlated with the length of mycorrhiza-colonised root for some eco mycorrhiza species. In other cases, the benefits of EM inoculation are more clear-cut and this approach has been used the establishment and growth of young transplant in horticulture and forestry e.g. Eucalyptus tereticornus [74], Acacia tortilis [75], Pinus species [76]. 


\section{Mycorrhizal Fungi and Phosphorus Nutrition}

A primary effect of mycorrhizal symbiosis is improved $\mathrm{P}$ nutrition made possible by the extensive hyphal network This not only allows the plant to overcome the $\mathrm{P}$ depletion zone around the root but also allows it to reach immobile $\mathrm{P}$ that the fungus can solubilise. This phenomenon is most apparent in low $\mathrm{P}$ soils. $\mathrm{P}$ can substitute the effects of mycorrhizal infection on plant survival in non-mycorrhizal controls in many cases. However, with increasing soil P, the benefits of mycorrhizal infection decline and mycorrhizal infection is reduced. In general, the benefits of mycorrhizas are lost to plants that have other means of obtaining $\mathrm{P}$ from the soil. The use of fertilizers in conventional farming ignores the activity of mycorrhizal fungi. This could have important long-term consequences for crop production.

\section{Effect of Microbioms on Soil Health}

Some Microbial communities affect directly or indirectly the plant physiology, nutritional and physico-chemical properties of rhizospheric soils through their metabolic activities. PGPR are important components of integrated farming, which help to nourish the crops through required nutrients. These PGPR help to fix atmospheric nitrogen; solubilize and mobilize phosphorus; translocate minor elements like $\mathrm{Mo}, \mathrm{Zn}, \mathrm{Cu}$, etc. to the plants; produce plant growth-promoting hormones like IAA and GA; and improve soil structure by production of polysaccharides, thus helps to improve the soil health and increase crop production. They are reported to increase uptake of nutrient elements like $\mathrm{Ca}$, $\mathrm{K}, \mathrm{Fe}, \mathrm{Cu}, \mathrm{Mn}$ and $\mathrm{Zn}$ through proton pump ATPase [77]. The importance of PGPR on maintaining soil fertility is well studied by many scientists $[78,79]$. Inoculation of seeds with PGPR significantly increased the values of available $P$, microbial population, acid phosphatase, alkaline phosphatase, dehydrogenase activity in soil and yields over uninoculated seeds [80].

\section{Microbial Biotechnology and Environmental Health}

Bruce Rittmann, director of the Center for Environmental Biotechnology in the Biodesign Institute at ASU, addressed the challenges and solution of environmental health by manipulation of microbes [81], their solution: a synergistic marriage of two distinct disciplines, microbial ecology and environmental biotechnology. "Together, they offer much promise for helping society deal with some of its greatest challenges in environmental quality, sustainability, security, and human health," Rittmann stated in an excerpt from the paper [82]. Leading the marriage are revolutionary changes in compiling vast amounts of genetic information on microbial organisms through state-of-the-art DNA-based techniques. Identifying just a single microbial specimen is a daunting task, considering, that there may be trillions of bacteria in every litre of water.

To aid in the identification and function of individual micro-organisms and communities, the first use of modern molecular biology tools began in the early 1980s, with the advent of polymerase chain reaction (PCR) amplification of microbial DNA and a new view of the evolution of organisms based on the ribosomal RNA. These technologies have advanced into high-throughput genomic and proteomic protocols that can detect specific genes and their metabolic functions with great precision and detail. Other methods can now reconstruct entire genomes of what were once "uncultivable" microbes. With recent advances in biology, materials, computing, and engineering, environmental biotechnologists now are able to use microbial communities for a wealth of services to society [83].

These include detoxifying contaminated water, wastewater, sludge, sediment, or soil; capturing renewable energy from biomass; sensing contaminants or pathogens; and protecting the public from dangerous exposure to pathogens. "Scientifically, it might be easiest to let the microbes convert the energy is organic wastes directly to electricity. However, they also can generate useful fuels, such as methane and hydrogen, and we are pursuing research on all of these renewable-energy forms." Rittman hoped the success in capturing the energy out of waste materials, this would be a world transforming technology and a real step forward to using more renewable forms of energy and much less reliance on fossil fuel."

\section{Conclusion}

Exploiting the interactions between soil microbial communities and crops is a relevant approach to increase food production for the growing world population at the lowest environmental costs, in the current scenario of global change. Essentially, there are two major strategies for managing the soil microbiomes, these are being based either on the development of microbial inoculants or on the manipulation of naturally existing microbial populations. Past few decades the human population has doubled. Food production has similarly increased. Use of human-made fertilizers has enabled much of the increase in crop production. Concurrent with the escalating use of commercial fertilizers, the intensity of agricultural practices have increased, and a wide variety of fungicides, bactericides, and pesticides are utilized in large-scale crop production. The increasing concern of consumers and government on food safety has led growers to explore new environmentally friendly methods to replace, or at least supplement, the current chemical-based practices. The use of bio-pesticides, bio-herbicides and bio-insecticides has emerged as promising alternative to chemical pesticides products.

The integration of microbial bio-fertilizers, bio-control microbes, optimized microbiomes, soil amendments and matching microbe-optimized crops for different soil types 
would be the ultimate goal for enhancing plant-microbe interactions. Clearly, this is a largely untapped area that deserves major research efforts, as it holds the promise to improve crop yields and address food security in an environmentally friendly and sustainable manner. Overall, existing microbial technologies along with emerging microbiome and associated approaches offer new and more sustainable practices to increase agriculture productivity. Initial assessments highlight growing demand for microbialbased solutions for food security both from growers and consumers of the produce. However, significant scientific and technological challenges exist. If these challenges can be prioritized along with the improvement of regulatory framework, emerging microbial based solutions can potentially transform sustainable agriculture.

The target research topics offer many challenges because there are many gaps in our understanding. As a general conclusion, we can say that many achievements have been reached with the application of microbial biotechnology in agriculture but many challenges as well as opportunities need to be explored for the future sustainable agricultural developments.

\section{Abbreviations}

PGPR, plant growth promoting rhizobacteria; VAM, vesicular arbuscular mycorrihiza; BGA, blue green algae; PSB, phosphorus solublizing bacteria; EPA, environmental protection agency; BT, bacillus thuringiensis.

\section{References}

[1] Tilman, D., Cassman, K. G., Matson, P. A., Naylor, R., and Polasky, S. (2002). Agricultural sustainability and intensive production practices. Nature 418: 671-677.

[2] Vance C. P. (1998). Legume symbiotic nitrogen fixation: agronomic aspects. In The Rhizobiaceae. Molecular Biology of Model Plant-Associated Bacteria, pp. 509-530. Eds. H. P. Spaink, A. Kondorosi.

[3] Noble A. D., Ruaysoongnern S. (2010). The nature of sustainable agriculture. In Soil Microbiology and Sustainable Crop Production, pp. 1-25. Eds R. Dixon and E. Tilston. Berlin, Heidelberg, Germany: Springer Science and Business Media B. V.

[4] Ahirwar, N. K., Gupta, G., and Singh, V. (2015). Biodegradation of Chromium Contaminated Soil by Some Bacterial Species. International Journal of Science and Research. 4: 1024-1029.

[5] Browne, P., Barret, M., Morrissey, J. P., O'Gara, F. (2013). Molecular-based strategies to exploit the inorganic phosphatesolubilization ability of Pseudomonas in Sustainable Agriculture. In: F. J. de Bruijn (ed). Molecular Microbial Ecology of the Rhizosphere, vol 2. Wiley Blackwell, Hoboken, New Jersey, USA, pp: 615-628.

[6] Narendra Kumar Ahirwar, Govind Gupta, Ravindra Singh and Vinod Singh. (2018). Assessment of Present Heavy Metals in Industrial Affected Soil Area of Mandideep, Madhya Pradesh,
India. Int. J. Curr. Microbiol. App. Sci. 7 (1): 3572-3582. https://doi.org/10.20546/ijcmas.2018.701.419.

[7] Ramana, S, Biswas, A. K., Ajay, Singh, A. B., Ahirwar, N. K. (2012). Phytoremediation of chromium by tuberose. National Academy Sci. Lett. 35 (2): 71-73.

[8] S. Ramana, A. K. Biswas, Ajay, A. B. Singh, N. K. Ahirwar A. \&Subba Rao (October-December 2013). Potential of rose for phytostabilization of chromium contaminated soils Ind J Plant Physiol. 18 (4): 381-383 DOI 10.1007/s40502-013-0055-6.

[9] Ramana, S., Biswas, A. K., Ajay, Singh, A. B., Ahirwar, N. K. (2013). Evaluation of phytoremediation ability of some floricultural plant species. Indian J Plant Physiol 18 (2): 187190 DOI 10. 1007/s40502-013-0029-8.

[10] Ramana, S., Biswas, A. K., Singh, A. B., Ajay, Ahirwar, N. K., Rao, S. (2014). Tolerance of Ornamental Succulent Plant Crown of Thorns (Euphorbia milli) to Chromium and its Remediation, International Journal of Phytoremediation, 17 (4): $363-368$.

[11] Duarte, C. M., Alonso, S., Benito, G., Dachs, J., Fernández Ríos, A. d. 1. A., Montes, C., Pardo, M., Simó, R., Valladares, F. (2006). Cambio global: Impacto de la actividadhumanasobre el sistemaTierra. Consejo Superior de Investigaciones Científicas (CSIC).

[12] Vitousek, P. M., Mooney, H. A., Lubchenco, J., Melillo, J. M. (1997). Human domination of Earth's ecosystems. Science 277, 494-499.

[13] Altieri, M. A. (2004). Linking ecologists and traditional farmers in the search for sustainable agriculture. Front. Ecol. Environ. 2, 35-42.

[14] Zancarini, A., Lépinay, C., Burstin, J., Duc, G., Lemanceau, P., Moreau, D., Munier-Jolain, N., Pivato, B., Rigaud, T., Salon, C., Mougel, C. (2013). Combining molecular microbial ecology with ecophysiology and plant genetics for a better understanding of plant-microbial communities' interactions in the rhizosphere. In: F. J. de Bruijn (ed). Molecular Microbial Ecology of the Rhizosphere, vol 1. Wiley Blackwell, Hoboken, New Jersey, USA, pp: 69-86.

[15] Zolla, G., Bakker, M. G., Badri, D. V., Chaparro, J. M., Sheflin, A. M., Manter, D. K., Vivanco, J. (2013). Understanding root-microbiome interactions. In: F. J. de Bruijn (ed). Molecular Microbial Ecology of the Rhizosphere, vol 2. Wiley Blackwell, pp: 745-754.

[16] Leong, J., (1986). Siderophore: their biochemistry and possible role in biocontrol of plant pathogens. Annu Rev Phytopathol. 24: 187-209.

[17] Ramana, S., Biswas, A. K., Singh, A. B., Ajay, Ahirwar, N. K., Ravulapalli, D., Srivastava, P. \& Subbar Rao S. (2015). Potential of Mauritius Hemp (Furcraeagigantea Vent. ) for the Remediation of Chromium Contaminated Soils, International Journal of Phytoremediation, 17 (7): 709-715.

[18] Ongena M, Jacques P. (2008). Bacillus lipopeptides: versatile weapons for plant disease biocontrol. Trends Microbiol 16: 115-125.

[19] Ahirwar, N. K., Gupta, G., Singh, R. and Singh, V. (2016). Isolation, Identification and Characterization of Heavy Metal Resistant Bacteria from Industrial Affected Soil in Central India, Int. J. Pure App. Biosci. 4 (6): 88-93. 
[20] Ramana, S., Biswas, A. K., Ajay, \&Subba Rao, A. (2008a). Tolerance and bioaccumulation of cadmium and lead by gladiolus. National Academy Science Letters, 30 (11), 327332 .

[21] Ahirwar, N. K., Singh, R. and Gupta, P. K. (2018). Bacterial Approaches for Reclamination of Chromium (VI) Polluted Soil, Int. J. Pure App. Biosci. 6 (2): $782-792$ doi http://dx.doi.org/10.18782/2320-7051. 6401.

[22] Bhardwaj D, Ansari MW, Sahoo RK, Tuteja N (2014). Biofertilizers function as key player in sustainable agriculture by improving soil fertility, plant tolerance and crop productivity. Microb Cell Fact 13: 66.

[23] Stein $T$ (2005). Bacillus subtilis antibiotics: structures, syntheses and specific functions. Mol Microbiol 56: 845-857.

[24] Jacques P (2011). Surfactin and other lipopeptides from Bacillus spp. Microbiol Monogr 20: 57-91.

[25] Gupta, G., Parihar, S. S., Ahirwar, N. K., Snehi, S. K., and Singh, V. (2015). Plant Growth Promoting Rhizobacteria (PGPR): Current and Future Prospects for Development of Sustainable Agriculture. J Microb Biochem Technol. 7: 096-102.

[26] Sinha RK, Valani D, Chauhan K, Agarwal S. (2014). Embarking on a second green revolution for sustainable agriculture by vermiculture biotechnology using earthworms: reviving the dreams of Sir Charles Darwin. Int J Agric Health Saf 1: 50-64.

[27] Copping LG, Menn J J (2000). Biopesticides: a review of their action, applicationsand efficacy. Pest ManagSci 56: 651-676.

[28] Fravel D R (2005). Commercialization and implementation of biocontrol. AnnuRev Plant Physiol Plant MolBiol 43: 337359 .

[29] Couillerot O, Prigent-Combaret C, Caballero-Mellado J, Moënne-Loccoz Y (2009). Pseudomonas fluorescens and closely-related fluorescent pseudomonadsas biocontrol agents of soil-borne phytopathogens. Lett ApplMicrobiol48: 505-512.

[30] N. K. Ahirwar, G. Gupta, V. Singh, R. K. Rawlley, and S. Ramana (2015). Influence on growth, physiology, and fruit yield of tomato (Lycopersiconesculentum Mill.) plants by inoculation with Pseudomonas fluorescence (SS5): A possible role of plant growth promotion. Int. J of Current Microbiology \& Applied Science, 4: (2). 720-730.

[31] Kloepper JW, Lifshitz R, Zablotowicz R M (1989). Freeliving bacterial inocula for enhancing crop productivity. Trends Biotechnol 7: 39-43.

[32] Glick BR (2004). Teamwork in phytoremediation. Nat Biotechnol 22: 526-527.

[33] Ahmad R, Arshad M, Khalid A, Zahir ZA (2008). Effectiveness of organic-/bio-fertilizer supplemented with chemical fertilizers for improving soil water retention, aggregate stability, growth and nutrients uptake of maize (Zea mays L.) J Sustain Agric 31: 57.

[34] Kohler J, Hernandez JA, Caravaca F, Roldan A (2009). Induction of antioxidant enzymes is involved in the greater effectiveness of a PGPR versus AM fungi with respect to increasing the tolerance of lettuce to severe salt stress. Environ Exp Bot 65: 245-252.

[35] Kumar A, Maurya B R, Raghuwanshi R, Meena V S, Islam M
T (2017). Co-inoculation with Enterobacter and Rhizobacteria on yield and nutrient uptake by wheat (Triticumaestivum L.) in the alluvial soil under indo-gangetic plain of India. J Plant Growth Regul. https://doi.org/10.1007/s00344-016-9663-5.

[36] Dotaniya ML, Meena VD, Basak BB, Meena RS (2016). Potassium uptake by crops as well as microorganisms. In: Meena VS, Maurya BR, Verma JP, Meena RS (eds) Potassium solubilizing microorganisms for sustainable agriculture. Springer, New Delhi, pp 267-280. https://doi.org/10.1007/978-81-322-2776-2_19.

[37] Philippot L, Raaijmakers JM, Lemanceau P, van der Putten WH (2013). Going back to the roots: the microbial ecology of the rhizosphere. Nat Rev Microbiol 11: 789-799.

[38] Babalola O O, Kirby B M, Roes-Hill L, Cook A E, Cary S C, Burton S G, Cowan D A (2009). Phylogenetic analysis of actinobacterial populations associated with Antarctic Dry Valley mineral soils. Environ Microbiol 11 (3): 566-576.

[39] Gupta A K (2004). The complete technology book on biofertilizers and organic farming. NationalInstitute of Industrial Research Press, New Delhi.

[40] Meena VS, Bahadur I, Maurya BR, Kumar A, Meena RK, Meena SK, Verma JP (2016d). Potassium-solubilizing microorganism in evergreen agriculture: an overview. In: Meena VS, Maurya BR, Verma JP, Meena RS (eds) Potassium solubilizing microorganisms for sustainable agriculture. Springer, New Delhi, pp 1-20. https://doi.org/10.1007/978-81-322-2776-2 1.

[41] Teotia P, Kumar V, Kumar M, Shrivastava N, Varma A (2016). Rhizosphere microbes: potassium solubilization and crop productivity-present and future aspects. In: Meena VS, Maurya BR, Verma JP, Meena RS (eds) Potassium solubilizing microorganisms for sustainable agriculture. Springer, New Delhi, pp 315-325. https://doi.org/10.1007/978-81-322-2776-2_22.

[42] Gupta S and Dikshit AK. (2010). Biopesticides: An ecofriendly approach for pest control. Journal of Biopesticides.; 3 (1): 186-188.

[43] Salma Mazid. (2011). A review on the use of biopesticides in insect pest management International Journal of Science and Advanced Technology.; 1 (7): 169-178.

[44] Kalra A and Khanuja SPS (2007). Research and Development priorities for biopesticide and biofertiliser products for sustainable agriculture in India, In. Business Potential for Agricultural Biotechnology (Teng, P. S. ed. ), Asian Productivity Organisation.; 96-102.

[45] Roh JY, Choi JY, Li MS, Jin BR and Je YH (2007). Bacillus thuringiensis as a specific, safe, and effective tool for insect pest control. J Microbiol Biotechnol.; 17: 547-559.

[46] Kumar S, Chandra A and Pandey KC. (2008). Bacillus thuringiensis $(\mathrm{Bt})$ transgenic crop: an environmentally friendly insect-pest management strategy. J Environ Biol.; 29: 641-653.

[47] Hoagland, R. E., Weaver, M. A., Boyette, C. D. (2007). Myrothecium verrucaria fungus; Abioherbicide and strategies to reduce its non-target risks. Allelopathy Journal, 19 (1): 179192.

[48] Singh, H. P., Batish, D. R., Kohli, R. K. (2006). Handbook of Sustainable Weed Management. Food Products press. Binghamton, NY. 
[49] Buss EA and Park-Brown SG. (2002). Natural Products for Insect Pest Management. ENY- 350 (http://edis.ifas.ufl.edu/IN197).

[50] Nicholson GM. (2007). Fighting the global pest problem: Preface to the special Toxicon issue on insecticidal toxins and their potential for insect pest control. Toxicon.; 49: 413422 .

[51] Mueller, U. G., and Sachs, J. L. (2015). Engineering microbiomes to improve plant and animal health. Trends Microbiol 23: 606-617.

[52] Singh, B. K., and Trivedi, P. (2017). Microbiome and the future for food and nutrient security. MicrobBiotechnol10: $50-53$.

[53] Berendsen, R. L., Pieterse, C. M., and Bakker, P. A. (2012). The rhizosphere microbiome and plant health. Trends Plant Sci 17: $478-486$.

[54] Yang J., Kloepper J. W., Ryu C. M. (2009). Rhizosphere bacteria help plants tolerate abiotic stress. Trends in Plant Science, 14, 1-4.

[55] Wang H. R., Wang M. Z., Yu L. H. (2009). Effects of dietary protein sources on the rumen microorganisms and fermentation of goats. Journal of Animal and Veterinary Advances, 7, 1392-1401.

[56] Mohammed S. H., Seady M. A., Enan M. R., Ibrahim N. E., Ghareeb A., Moustafa S. A. (2008). Biocontrol efficiency of Bacillus thuringiensis toxins against root-knot nematode, Meloidogyne incognita. Journal of Cell and Molecular Biology, 7, 57-66.

[57] FrancheC., Lindstrom K., Elmerich C. (2009). Nitrogen-fixing bacteria associated with leguminous and non-leguminous plants. Plant and Soil, 321, 35-59.

[58] Arnold A. E., Mamit L. J., Gehring C. A., Bidartondo M. I., C allahan H. (2010). Interwoven branches of the plant and fungal trees of life. New Phytologist, 185, 874-878.

[59] Peay K. G., Bidartondo M. I., Arnold A. E. (2010). Not every fungus is everywhere: scaling to the biogeography of fungalplant interactions across roots, shoots and ecosystems. New Phytologist, 185, 878-882.

[60] Provorov N. A., Tikhonovich I. A. (2003). Genetic resources for improving nitrogen fixation in legume-rhizobia symbiosis. Genetic Resources and Crop Evolution, 50, 89-99.

[61] Provorov N. A., Saimnazarov U. B., Bahromov I. U., Pulatova D. Z., Kozhemyakov A. P., Kurbanov G. A. (1998). Effect of rhizobia inoculation on the seed (herbage) production of mungbean (Phaseolus aureus Roxb.) grown at Uzbekistan. Journal of Arid Environments, 39, 569-575.

[62] Andrews M., Hodge S., Raven J. A. (2009). Positive plant microbial interactions. Annals of AppliedBiology, 157, 317320 .

[63] Hedin L. O., Brookshire E. N. J., Menge D. N. L., Barron A. R. (2009). The nitrogen paradox in tropical forest ecosystems. Annual Review of Ecology, Evolution and Systematics, 40, 613-635.

[64] Ahmad M, Nadeem SM, Naveed M, Zahir ZA (2016b). Potassium - solubilizing bacteria and theirapplication in agriculture. In: Meena VS, Maurya BR, Verma JP, Meena RS (eds) Potassiumsolubilizing microorganisms for sustainable agriculture. Springer, New Delhi, pp 293-313https://doi. org/10.1007/978-81-322-2776-2_21.

[65] Provorov N. A., Vorobyov N. I. (2009). Host plant as an organizer of microbial evolution in the beneficial symbioses. Phytochemistry Reviews, 8, 519-534.

[66] Shtark O. Y., Borisov A. Y., Zhukov V. A., Provorov N. A., Tikhonovich I. A. (2010). Intimate associations of beneficial soil microbes with host plants. Soil Microbiology and Sustainable Crop Production, pp. 119-196. Eds R. Dixon and E. Tilston. Berlin, Heidelberg, Germany: Springer Science and Business Media B. V and P. J. J. Hooykaas. Dordrecht, the Netherlands: Kluwer Academic Publishers.

[67] Ryan R. P., Germaine K., Franks A., Ryan D. J., Dowling D. N. (2008). Bacterial endophytes: recent developments and applications. FEMS Microbiology Letters, 278, 1-9.

[68] Kupriyanov A. A., Semenov A. M., Van Bruggen A. H. C. (2010). Transition of entheropathogenic and saprotrophic bacteria in the niche cycle: animals-excrement-soil-plantsanimals. Biology Bulletin, 3, 263-267.

[69] Cooper, K. M. and G. S. Grandison (1986). Interactions of VAM fungi and root knot nematode on cultivars of tomato and white clover susceptible to Meloidogynehalpa. Annals of AppliedBiology, 108: 555-565.

[70] Dehne, H. W. (1982). Interactions between vesicular arboscular mycorrhizal fungi and plant pathogens. Phytopathology, 72: 1115-1118.

[71] Parke, J. F.; R. G. Linderman and C. H. Black (1983). The role of ectomycorrhizas in drought tolerance of Douglas fir seedlings. New Phytologist, 95: 83-95.

[72] Duponnois, R. and A. M. Ba (1998). Influence of the microbial community of a sahel soil on the interactions between Meloidogynejavanica and Pasteuriapenetrans. Nematologica, 44: 331-343.

[73] Leyval, C.; K. Turnau and K. Haselwandter (1997). Effect of heavy metal pollution on mycorrhizal colonization and functions: physiological, ecological and applied aspects. Mycorrhiza, 7 (3): 139-153.

[74] M. V. Reddy and Okhura (2004). "Vermicomposting of ricestraw and its effects on sorghum growth," Tropical Ecology, vol. 45 , pp. $327-331$.

[75] Munro, R. C.; J. Wilson, J. Jefwa and K. W. Mbuthia (1999). A lowcost method of mycorrhizal inoculation improves growth of Acacia tortilis seedlings in the nursery. Forest Ecology and Management, 113 (1): 51-56.

[76] Scagel, C. F. and R. G. Linderman (1998). Influence of ectomycorrhizal fungal inoculation on growth and root IAA concentrations of transplanted conifers. Tree Physiology, 18: 739-747.

[77] Mantelin S, Touraine B (2004). Plant growth-promoting bacteria and nitrate availability: impacts on root development and nitrate uptake. J Exp Bot 55: 2734.https://doi.org/10.1093/jxb/erh010.

[78] Das I, Singh AP (2014). Effect of PGPR and organic manures on soil properties of organically cultivated mungbean. The Bioscan 9 (1): 27-29. 
[79] Ravindra Singh, Narendra Kumar Ahirwar, Jagrati Tiwari \&Jyotsana Pathak (2018). Review On Sources And Effect Of Heavy Metal In Soil: Its Bioremediation IMPACT: International Journal of Research in Applied, Natural and Social Sciences Special Edition, Aug., PP, 8: 1-22.

[80] Hemashenpagam N, Selvaraj T. (2011). Effect of arbuscular mycorrhizal (AM) fungus and plant growth promoting rhizomicroorganisms (PGPR's) on medicinal plant Solanum viarum seedlings. J Environ Biol 32: 579-583.
[81] http://www.csrees.usda.gov/nea/biotech/infocus/biotechnolog $\mathrm{y}$ if microbial.html.

[82] http://microbialbiotechnology.puchd.ac. in: Centre for Microbial Biotechnology.

[83] Rittmann Bruce, director of the Center for Environmental Biotechnology in the Biodesign Institute at ASU, http//:www.biodesign.asu.edu. Center for Environmental Biotechnology. 